\title{
Diverse microbial communities hosted by the model carnivorous pitcher plant Sarracenia purpurea: Analysis of both bacterial and eukaryotic composition across distinct host plant populations
}

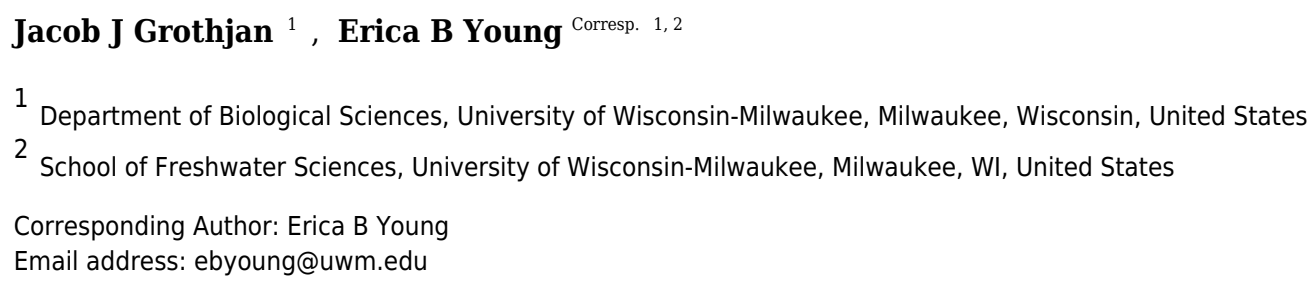

Background. The pitcher plant Sarracenia purpurea supplements nutrient acquisition through carnivory, capturing insect prey which are digested by a food web community of eukaryotes and bacteria. While the food web invertebrates are well studied, and some recent studies have characterized bacteria, detailed genetic analysis of eukaryotic diversity is lacking. This study aimed to compare eukaryotic and bacterial composition and diversity of pitcher communities within and between populations of host plants in nearby but distinct wetland habitats, and to characterize microbial functions across populations and in comparison with another freshwater community. Methods. Pitcher fluid was sampled from the two wetlands, Cedarburg and Sapa bogs, community DNA was extracted, and 16S and 18S rRNA amplicons were sequenced and data processed for community-level comparisons. Results and Conclusions. Bacterial diversity in the small pitcher volume rivaled that of larger aquatic communities. Between pitcher plant populations, several bacterial families (Kiloniellaceae, Acetobacteraceae, Xanthobacteraceae, Sanguibacteraceae, Oligoflexaceae, Nitrosomonadaceae, Chromatiaceae, Saprospiraceae) were significantly higher in one population. However, although predicted pitcher bacterial functions were distinct from other freshwater communities, especially for some amino acid metabolism, functions were similar across all the pitchers in the two populations. This suggests some functional redundancy among bacterial taxa, and that functions converge to achieve similar food web processes. The sequencing identified a previously under-appreciated high diversity of ciliates, Acari mites, fungi and flagellates in pitcher communities; the most abundant sequences from eukaryotic taxa were Oligohymenophorea ciliates, millipedes and Ichthyosporea flagellates. Two thirds of taxa were identified as food web inhabitants and less than one third as prey organisms. Although eukaryotic composition was not significantly different 
between populations, there were different species of core taxonomic groups present in different pitchers - these differences may be driven by wetland habitats providing different populations to colonize new pitchers. Eukaryotic composition was more variable than bacterial composition, and there was a poor relationship between bacterial and eukaryotic composition within individual pitchers, suggesting that colonization by eukaryotes may be more stochastic than for bacteria, and bacterial recruitment to pitchers may involve factors other than prey capture and colonization by eukaryotic food web inhabitants. 
1 Diverse microbial communities hosted by the model carnivorous pitcher plant Sarracenia purpurea:

2 Analysis of both bacterial and eukaryotic composition across distinct host plant populations

3

4

5

6 Jacob J. Grothjan ${ }^{1}$ and Erica B. Young ${ }^{2}$

$7{ }^{1}$ Department of Biological Sciences, University of Wisconsin-Milwaukee, 3209 N Maryland Ave,

8 Milwaukee, WI 53211, USA

9 2Department of Biological Sciences, University of Wisconsin-Milwaukee, 3209 N Maryland Ave,

10 Milwaukee WI 53211 and School of Freshwater Sciences, University of Wisconsin-Milwaukee, 600 E

11 Greenfield Ave, Milwaukee, WI 53204, USA

12

14 Corresponding Author:

15 Erica B. Young ${ }^{1}$

$16{ }^{1}$ Department of Biological Sciences, University of Wisconsin-Milwaukee, 3209 N Maryland Ave,

17 Milwaukee, WI 53211, USA

18 Email address: ebyoung@uwm.edu

19

20 


\section{ABSTRACT}

22 Background. The pitcher plant Sarracenia purpurea supplements nutrient acquisition through carnivory,

23 capturing insect prey which are digested by a food web community of eukaryotes and bacteria. While the

food web invertebrates are well studied, and some recent studies have characterized bacteria, detailed genetic analysis of eukaryotic diversity is lacking. This study aimed to compare eukaryotic and bacterial composition and diversity of pitcher communities within and between populations of host plants in nearby but distinct wetland habitats, and to characterize microbial functions across populations and in comparison with another freshwater community.

Methods. Pitcher fluid was sampled from the two wetlands, Cedarburg and Sapa bogs, community DNA was extracted, and 16S and 18S rRNA amplicons were sequenced and data processed for communitylevel comparisons.

Results and Conclusions. Bacterial diversity in the small pitcher volume rivaled that of larger aquatic communities. Between pitcher plant populations, several bacterial families (Kiloniellaceae, Acetobacteraceae, Xanthobacteraceae, Sanguibacteraceae, Oligoflexaceae, Nitrosomonadaceae, Chromatiaceae, Saprospiraceae) were significantly higher in one population. However, although predicted pitcher bacterial functions were distinct from other freshwater communities, especially for some amino acid metabolism, functions were similar across all the pitchers in the two populations. This suggests some functional redundancy among bacterial taxa, and that functions converge to achieve similar food web processes. The sequencing identified a previously under-appreciated high diversity of ciliates, Acari mites, fungi and flagellates in pitcher communities; the most abundant sequences from eukaryotic taxa were Oligohymenophorea ciliates, millipedes and Ichthyosporea flagellates. Two thirds of taxa were identified as food web inhabitants and less than one third as prey organisms. Although eukaryotic composition was not significantly different between populations, there were different species of core taxonomic groups present in different pitchers - these differences may be driven by wetland habitats providing different populations to colonize new pitchers. Eukaryotic composition was more variable than 
46 bacterial composition, and there was a poor relationship between bacterial and eukaryotic composition

47 within individual pitchers, suggesting that colonization by eukaryotes may be more stochastic than for

48 bacteria, and bacterial recruitment to pitchers may involve factors other than prey capture and

49 colonization by eukaryotic food web inhabitants.

\section{INTRODUCTION}

Carnivorous plants grow in nutrient deficient wetlands environments and use carnivory to supplement their mineral nutrition, and include Venus fly traps, sundews, and pitcher plants (Ellison \& Adamec, 2018). The northern or purple pitcher plant, Sarracenia purpurea subsp. purpurea L. produces modified leaves formed into pitchers that function as passive pitfall traps which fill with rainwater and capture insect prey. Breakdown of insect prey in S. purpurea is achieved by an inquiline (living in the pitcher habitat) food web of invertebrates and microbes which colonize after pitcher opening (Peterson et al., 2008). The microbes produce digestive enzymes to release nutrients from organic prey particles to support the food web and provide nutrients for host plant uptake (Young, Sielicki \& Grothjan, 2018). Core invertebrate trophic levels of the food web are well characterized (Gotelli \& Ellison, 2006; Mouquet et al., 2008) and recent studies provide some insights into the bacteria present (Gray et al., 2012) but we have limited understanding of the functions of microbial communities or diversity of eukaryotic microbes represented within the $S$. purpurea pitcher plant food web. (Peterson et al., 2008), then the pitcher community changes over time with succession, and may be regulated by resource availability (Miller \& TerHorst, 2012; Gray et al., 2012; Armitage, 2017). The invertebrate taxa of the food web have several known functions; Sarcophagid fly larvae shred insect prey and stir the fluid, midges live at the base of the pitcher, breaking apart detritus, and rotifers and ciliates are mid-trophic level grazers (Bledzki \& Ellison, 1998; Paisie, Miller \& Mason, 2014). The mosquito 
71 larvae, Wyeomyia smithii is a top predator grazer in pitcher plant food webs (Kneitel \& Miller, 2002;

72 Baiser et al., 2013). Autotrophic algae may be present in pitchers (Gebühr et al., 2006). The composition

73 of pitcher inhabitants is known to vary between individual pitchers and across plant populations (Peterson

74 et al., 2008; Gray, 2012), but little is known about the relationship between eukaryotic and bacterial

75 composition of the communities, between pitchers and across pitcher plant populations. While genetic

76 sequencing has provided detailed information about bacterial communities in Sarracenia communities

77 (Koopman \& Carstens, 2011; Gray et al., 2012) and limited genetic analysis has targeted eukaryotes in

78 other carnivorous plant species (TerHorst, 2011; Bittleston et al., 2016; Satler, Zellmer \& Carstens,

79 2016), detailed genetic analysis of the eukaryotic communities using rRNA targets has not previously

80 been applied to S. purpurea pitcher plant communities.

81 Microbial composition may vary with presence of other food web members and with

82 geographical distance ( Koopman \& Carstens, 2011; Paisie, Miller \& Mason, 2014; Bittleston et al.,

83 2018), and can be related to host habitat (Krieger \& Kourtev, 2012; Satler, Zellmer \& Carstens, 2016), but

84 how much microbial functions vary with host plant habitat or population is less clear. Pitcher plants show

85 acclimation to wetland habitats, for example, as changes in morphology related to carnivory in response

86 to nutrient availability (Gotelli \& Ellison, 2002). Two nearby wetlands in Wisconsin offer different

87 nutrient availability, $\mathrm{pH}$ and surrounding vegetation conditions which can induce morphological changes

88 in S. purpurea. In Sapa Bog, lower $\mathrm{pH}$, higher nitrogen and phosphorus in the soil water resulted in

89 narrower pitchers than Cedarburg Bog pitcher plants (Bott, Meyer \& Young, 2008). These two distinct

90 habitats and populations are ideal to compare food web composition, microbial diversity and function in

91 different $S$. purpurea populations in response to distinct habitat conditions.

92 Early isolation and culturing of pitcher plant bacteria identified a range of microbial functions

93 (Lindquist, 1975), and other studies applied genetic analysis techniques to cultured isolates (Whitman et

94 al., 2005; Siragusa, Swenson \& Casamatta, 2007) or identified particular functional groups of pitcher

95 plant bacteria (Young, Sielicki \& Grothjan, 2018). Recent studies have linked enzyme activity to bacterial

96 functions in nutrient cycling within S. purpurea pitchers (Luciano \& Newell, 2017; Bittleston et al., 2018; 
97 Young, Sielicki \& Grothjan, 2018). However, despite studies of bacterial diversity, characterization of

98 bacterial enzyme functions, the critical importance of bacteria in prey digestion and thus carbon and

99 nutrient supply to the food web, bacteria have only recently been considered as more than a 'black box' in

100 food web models (Lau et al., 2018). It is unknown if the microbial functions of the pitcher plant detrital

101 food web are similar to or distinct from other aquatic ecosystems. To understand what functions are

102 specific to these food webs and to expand the inclusion of bacterial functions in this model food web

103 system, more detailed information about pitcher plant bacterial community metabolic functions is needed.

104 To address these gaps in our understanding of eukaryotic diversity and bacterial functions in

105 pitcher plant communities and the variability between pitcher microbial populations, this study applied

106 mass gene sequencing and metagenomic functional predictions to compare microbial communities within

107 two distinct populations of S. purpurea. This study aimed to address the following specific research

108 questions:

109 1) How does the bacterial and eukaryotic taxa composition within Sarracenia purpurea pitchers

110 differ between pitchers within the same population and between two populations in nearby but

111 distinct wetland habitats?

2) How does the bacterial and eukaryotic diversity vary between S. purpurea pitchers in the two plant populations?

3) How do the predicted functions of the bacterial community compare between the plant populations and with another freshwater community?

\section{MATERIALS AND METHODS}

118 Site descriptions, plant selection, and sampling

119 Two populations of the pitcher plant Sarracenia purpurea subsp. purpurea (hereafter $S$.

120 purpurea) were sampled in June, 2013, from two distinct wetlands, $\sim 1.5 \mathrm{~km}$ apart, separated by farmland. 
121 One population was in the Cedarburg Bog $\left(43^{\circ} 23.2^{\prime} \mathrm{N}, 88^{\circ} 0.63^{\prime} \mathrm{W}\right)$, a peatland fen in SE Wisconsin

122 characterized by low lying marshy areas interspersed with elevated patches of cedar (Thuja occidentalis)

123 and tamarack (Larix laricina). S. purpurea grows in slightly elevated areas with sphagnum moss or open

124 marshy areas and the study site was accessed by a boardwalk. The second population was in an

125 ombrotrophic bog, Sapa $\operatorname{Bog}\left(43^{\circ} 23.64^{\prime} \mathrm{N}, 88^{\circ} 1.4^{\prime} \mathrm{W}\right)$ characterized by a dense growth of black spruce

126 (Picea mariana) and tamarack, providing a shadier canopy than in the Cedarburg Bog (Bott, Meyer \&

127 Young, 2008). The two populations experience different growth conditions with more acidic soil

128 substratum and higher plant available nitrogen $(\mathrm{N})$ and phosphorus $(\mathrm{P})$ in Sapa Bog (Bott, Meyer \&

129 Young, 2008). A field permit was issued by the University of Wisconsin-Milwaukee Field Station

130 committee.

131 S. purpurea pitchers were selected using the following criteria: 1) entirely green, avoiding any

132 sign of damage or senescence 2) with aperture $>3 \mathrm{~cm}$ to allow sampling with a syringe and 3) the fluid

133 contained suspended particles indicating active detrital and food web processes. Five samples were

134 collected from each of the two wetland population for a total of 10 samples. Some samples were from

135 single pitchers, others were combined samples from up to 3 separate pitchers to reach sample volume of

$136 \geq 30 \mathrm{~mL}$. Pitcher fluid was collected with a sterilized syringe and tubing inserted into the pitcher, and the

137 fluid mixed prior to sampling by drawing fluid into the syringe and dispelling (Young, Sielicki \&

138 Grothjan, 2018). Samples were transferred to sterile $50 \mathrm{~mL}$ tubes, stored on ice, and transported to the lab.

139 Samples were pre-filtered through $153 \mu \mathrm{m}$ mesh (Sefar NITEX, Montreal) to remove large debris, and

140 vacuum filtered onto $0.2 \mu \mathrm{m}$ polycarbonate membrane filters (GE Water and Process Technologies,

141 Pennsylvania) which were stored at $-70^{\circ} \mathrm{C}$.

142 DNA Extraction and Sequencing

143 Frozen filters with cells and particles were used for extraction of total community DNA using a

144 FAST DNA soil extraction kit (MP Biomedicals, Santa Ana, CA, USA). DNA concentration and purity

145 were confirmed with agarose gel electrophoresis and spectrophotometry (NanoDrop ND-1000). To

146 examine the bacterial and eukaryotic organisms represented in the pitcher fluid using genetic analysis, a 
147 range of PCR primers were tested for amplification of sequences from the total community DNA,

148 targeting the $16 \mathrm{~S}$ and $18 \mathrm{~S}$ rRNA genes. Gene targets producing the clearest and most consistent bands in

149 agarose gel electrophoresis were selected for use in DNA sequencing - 16S F338 (5'-

150 ACTCCTACGGRAGGCAGCAG-3’) (Dethlefsen et al., 2008) and R802 (5'-

151 TACNVGGGTATCTAATCC-3’) (Claesson et al., 2010) and 18S F426 (5’-

152 TCCAAGGAAGGCAGCAGG-3') and R853 (5'-AGTCCTATTCCATTATTCCATG-3') (Marron,

153 Akam \& Walker, 2013). Samples were sequenced by the Great Lakes Genomic Center at University of

154 Wisconsin-Milwaukee using 2 x 250 bp sequencing runs on an Illumina MiSeq using the 16S and 18S

155 rRNA primers with Illumina adapters and manufacturer protocols. The sequence depth was for $16 \mathrm{~S} 43-$

$156110 \mathrm{~K}$ reads and for $18 \mathrm{~S}$ was $99-147 \mathrm{~K}$ reads.

157 Sequence Analysis and Bioinformatics

158

159

160

161

162

163

164

165

166

167

168

169

170

171

172

16S rRNA V3_4 region sequences were analyzed with mothur version 1.33.3 with MiSeq SOP (accessed August 2014; (Kozich et al., 2013)) and with QIIME (MacQIIME V1.9.1). Quality control was performed by eliminating sequences with low quality scores and filtering chimeric sequences from samples using usearch (version 5.2.236; (Edgar, 2010)). Alignment and analysis of 16S sequences for taxonomic identity used the SILVA SSU database (Release 119, 123 (Quast et al., 2013)). Bacterial taxon richness and diversity were quantified by clustering sequences with a 97\% similarity OTU definition (Chao, 1984) using a de novo approach via the uclust algorithm (version v6.1.544) where individual sequences are treated as "seeds" from which to build clusters (Edgar, 2010).

18S rRNA V3_V4 sequences were analyzed in QIIME with SILVA SSU (release 123). Unzipped Forward (F) and Reverse (R) fastq data output files were joined (quality parameters $\mathrm{j}=75$ and $\mathrm{p}=0.9$ ) using fastq-join (Aronesty, 2011) in QIIME. Joined sequences that did not meet the minimum length threshold (464 bp for $16 \mathrm{~S}$ and $427 \mathrm{bp}$ for $18 \mathrm{~S}$ ) were removed. Sequences were separated from their quality scores and formatted for downstream processing using sed within UNIX command line). Chimeric sequences were removed via usearch v6.1 (Edgar, 2010) utilizing comparison with SILVA reference database (Release 123) for chimera detection and removal (Haas et al., 2011). Reads were clustered using 
173 a 97\% similarity OTU definition (Chao, 1984) using a de novo approach via the uclust algorithm (Edgar

174 et al., 2011) and sequences aligned using PyNAST (Caporaso et al., 2010), assigned taxonomy with the

175 BLAST algorithm (Edgar, 2010), using SILVA.

176 Community Comparisons

177 For comparison of the two plant populations, rarefaction curves were generated in QIIME and the

178 QIIME ANOSIM command was used to statistically test for similarities in community composition

179 between populations. Additional QIIME commands aided in downstream sequence analysis including

180 eliminating singletons from samples and using taxonomic composition to generate alpha and beta

181 diversity indices, and unifrac values for Principle Coordinate Analysis (PCoA) (Lozupone et al., 2011)

182 with plotting and visualization in PAST (Hammer, Harper \& Ryan, 2001) or for building sample

183 relatedness trees using FastTree 2.1 in QIIME (Price, Dehal \& Arkin, 2010). The taxa present in

184 significantly different frequencies in the two populations were identified using 1-way ANOVA of the 5

185 samples from each population using Sigmaplot (v12.5, Systat Software Inc, San Jose, CA, USA).

186 Diversity metrics were also compared between populations using 1-way ANOVA in Sigmaplot. Pitcher

187 community composition was compared in PCoA and relatedness trees using outgroups generated from

188 freshwater wastewater bacterial communities (Xiao et al., 2015) for 16S, and freshwater eukaryotic

189 database (EUKBASE) created from SILVA NR108 (Pruesse et al., 2007) for 18S rRNA sequences. 16S

190 rRNA sequences and taxon identities were used to predict metagenomic functional gene categories using

191 PICRUSt based on KEGG biochemical pathways (Langille et al., 2013) with weighted NSTI scores of

$1920.03-0.39$ for pitchers and 0.12-0.33 for the comparison freshwater community. PICRUSt functional data

193 was used for PCoA analysis using HUMAnN2 v0.11.1 (Abubucker et al., 2012), and functional gene

194 category predictions were compared across samples and with the wastewater bacterial communities

RESULTS

197

Bacterial and Eukaryotic Taxa in Pitcher Fluid 
The bacterial and eukaryotic community composition of individual pitchers varied, with some

199

200

201

202

203

204

205

206

207

208

209

210

211

212

213

214

215

216

217

218

219

220

221

222

223

pitchers very similar in composition, others distinct (Fig. 1). Based on sequence identity, the bacterial families were typically represented more evenly within each pitcher than Eukaryotic families, as most pitcher samples were dominated by relatively few Eukaryotic families, though the dominant Eukaryotic families varied across pitchers (Fig. 1). Pitchers sampled in Cedarburg were more similar in bacterial composition than Sapa pitchers, and $\mathrm{CB} 1 \mathrm{p} 1$ and $\mathrm{CB} 1 \mathrm{p} 2$ are nearly identical in both bacterial and eukaryotic composition (Fig. 1). Some Sapa pitcher communities showed dominance of a single taxon, for example Sp3p4 was dominated by the bacterial family Coxiellaceae, and eukaryotic sequences were dominated by the ciliate taxon Scuticociliatia of which $84.6 \%$ was contributed from a single OTU. In other samples, single dominant taxa were comprised of several OTUs; in CB1p1 96.8\% of the sequences identified as Pseudomonadaceae were contributed from 5 OTUs. Taxonomic composition pooled for each wetland (Fig. S1), showed distinctions between the two populations, with more even representation of bacterial families in Cedarburg than in Sapa pitchers in which $>50 \%$ of sequences were attributed to 4 families (Fig. S1). In contrast, the pooled composition of Eukaryotic families for Cedarburg was dominated by 4 families, while Sapa communities showed more even representation of Eukaryotic families.

Comparison of composition of the most abundant bacterial and eukaryotic taxa between wetlands (Fig. 2), showed many common bacterial and eukaryotic families but with few families present in every sample (i.e., at least one sample showed 0 abundance). The heatmaps also illustrate that Cedarburg samples showed a greater number of common bacterial and eukaryotic OTUs between samples than Sapa samples (Fig. 2, Fig. S2). Bacterial composition of pitchers was dominated by groups Saccharibacteria (formerly candidate division TM7), $\alpha$ - $\beta$ - and $\gamma$-Proteobacteria, Bacteroidetes, Flavobacteria, and Firmicutes (Fig. 2). There were 10 bacterial families which were more abundant in one wetland population (ANOVA, p < 0.05, Fig. 2). Of the 15 most common bacterial families, only Neisseriaceae was significantly more abundant in Sapa samples $(\mathrm{p}<0.02)$ while 9 other less common bacterial families differed significantly between the two populations - Kiloniellaceae was also higher in Sapa samples ( $<<$ 
224 0.035) and Acetobacteraceae, Rhizobiales AT, Xanthobacteraceae, Sanguibacteraceae, Oligoflexaceae,

225 Nitrosomonadaceae, Chromatiaceae, Saprospiraceae were all higher in Cedarburg samples $(\mathrm{p}<0.05)$.

226 Across all pitchers, the highest abundance bacterial OTUs identified to genus included Rickettsiella,

227 Azospirillum, Pedobacter, Pseudomonas, Aquitalea, Sphingomonas, Duganella, and Alkanidiges (Table

228 S1).

Eukaryotic taxa present in the pitchers included different families of ciliates, millipedes,

230 springtails, midges, insects, fungi, flagellates, and other protists (Fig. 2, Table S2). Despite some

231 compositional differences in Eukaryotes between wetlands (Fig. S1), none of the Eukaryotic families

232 were found to be significantly more abundant in either wetland population (ANOVA, p > 0.05, Fig. 2).

233 However, clearly some taxa were dominant in some samples, but absent from others, and there were

234 many more Eukaryotic families only represented in one or two samples (e.g. Chytrid families, Gall

235 midges - Cecidomyiidae, land snails - Cochlicopidae, the Cryptomonad - Goniomonadaceae, and

236 Collembola - springtails). Detailed data on genus- and species-level identifications of eukaryotes present

237 in each sample are included in the supplementary materials (Table S2). Of the 25 most abundant taxa

238 identified, 8 were ciliate taxa, 8 were Arthropods ( 3 Acari mites, 3 insects), 5 were fungi, and 3 were

239 Opisthokont flagellates (Table S2). The two most common taxa identified were similar to an

240 Orchitophyridae ciliate environmental taxa (found in all 10 samples), and a Scuticociliata uncultured

241 taxon (found in 9 of 10 samples). The millipede species Cherokia georgiana was the most abundant

242 genus, present in 5 of 10 samples, an opisthokont flagellate Ichthyophonida_LKM51 was identified in all

24310 samples. Many taxa were only present in samples from one wetland but when major groups were

244 considered (Fig. 3), there were more arthropod and flagellates sequences in Cedarburg samples but more

245 ciliates in Sapa, although across the 5 samples in each wetland, there were no statistical differences

246 between abundance in Cedarburg vs Sapa (1-way ANOVA). Two different mosquito taxa of the family

247 Culicidae were identified in the two wetland populations (Table S2). The freshwater bdelloid rotifer

248 genus Adineta was represented in the similar Cedarburg CB1p1 and CB1p2 samples (Fig. 1), but not in

249 any other samples. Gastropod sequences were only found in 2 Sapa pitchers from the same plant, and 
250 tardigrade DNA was found in one Sapa sample (Table S2). Algae and plant sequences were present in

251 very low abundance in Sapa and were absent from Cedarburg pitchers. When Eukaryotic families were

252 scored as probable food web members vs prey, vs other, based on literature on habitat and organism

253 functions (Fig. 3), 67\% of sequences were identified as food web, 28\% of sequences were probable prey

254 and 5\% were ambiguous, potentially present incidentally (e.g. fungal spores or plant parts possibly fallen

255 into pitchers, taxa with unknown habitat or ecological role, or taxa of too broad a classification to make

256 grouping the organisms possible).

\section{Diversity Analysis}

258 Rarefaction curves for these samples are shown in Fig. S2, with no consistent coverage for 259 samples between 16S and 18S sequencing. Good's coverage estimate was high $(>0.95)$ across most 260 samples, except CB1p4 (Table 1). In bacterial diversity, Cedarburg samples showed significantly higher 261 number of OTUs, Chao1 richness, and ACE diversity, but also more singletons, than Sapa samples (1262 way ANOVA, $\mathrm{p}<0.025$; Table 1). Except for Sp5p23, all Cedarburg samples had more bacterial OTUs 263 than Sapa samples. The least diverse samples in terms of bacteria were from Sapa (Sp3p2, Sp3p4,

264 Sp9p234) but for eukaryotic composition, Cedarburg had the least diverse (CB1p1, CB1p2, CB1p3 and 265 CB1p4) as well as the most diverse sample (CB5p234). There were no significant differences in number 266 of OTUs or diversity metrics between the two populations of eukaryotes (Table 1).

\section{Community Comparisons and Functional Predictions}

268 PCoAs were based on bacterial composition using unifrac weighted jackknife settings, and 269 metagenome predictions from 16S rRNA-based taxonomic composition through PICRUSt (Fig. 4A).

270 There was close overlap in bacterial composition between Cedarburg and Sapa samples with no distinct

271 differences (ANOSIM $\mathrm{p}>0.05$ ), but the wastewater community used as an outgroup was distinct. Sp3p2,

272 Sp3p4, and Sp9p234 were more distant from the tight clustering of other pitcher samples. 
275 distinct functional profiles to the wastewater outgroup used (ANOSIM $p<0.01$ ). Functional vectors

276 driving separation included greater sulfur metabolism, photosynthesis and pigments, and starch and

277 sucrose metabolismin wastewater samples, which included algae and cyanobacteria, whereas the pitcher

278 communities were clustered with more prominent metabolism of several amino acids

279 The PCoA based on eukaryotic taxa also showed overlap between the two populations (Fig. 5).

280 Sapa samples were more different from each other than were Cedarburg samples, but both were distinct

281 from the EUKBASE freshwater compilation. Across all samples, eukaryotic composition of Cedarburg

282 versus Sapa samples was not significantly different (ANOSIM, $\mathrm{p}<0.25$ ). When the most common

283 family-level taxa were used as vectors to separate the two wetland populations in a NMDS plot (Fig. 5B),

284 population differences were driven by ciliate groups Colpodidae, Grossglockneriidae and Chytrids which

285 were more common in Sapa pitchers, and millipedes (Xystodesmidae), ciliates (Orchotophyridae) and

286 mosquitos (Culicidae) which were more common in Cedarburg (Fig. 2, Table S2). Presence or dominance

287 of additional ciliate, fungal or ant taxa also separated Sapa samples.

288

The relatedness trees show clustering of samples based on bacterial or Eukaryotic composition

289

(Fig. 6) support the PCoA clustering and taxon composition similarities (Figs 1, 4A) with CB1p1 and

290

CB1p2 showing the closest similarity (Fig. 6). However, there were no consistent clustering patterns for

291

both bacterial and eukaryotic composition, suggesting one did not follow the other. Sp3p2 and Sp9p234

292

were more similar in the 16S tree and share dominance of Saccharibacteria and Comamonadaceae and

293 absence of Coxiellaceae and Acetobacteraceae (Figs 1, 2), but these samples were not closely related in terms of Eukaryotic composition. Cedarburg and Sapa samples did not show distinct clustering in either tree (Fig. 6).

In comparing combined versus individual pitchers, some samples from the same plant were clearly very similar, e.g. $\mathrm{CB} 1 \mathrm{p} 1$ and $\mathrm{CB} 1 \mathrm{p} 2$, but others were not strikingly similar from the same plant (CB1p3 bacteria distinct from $\mathrm{CB} 1 \mathrm{p} 1$ and $\mathrm{CB} 1 \mathrm{p} 2$ (Fig. 6), and $\mathrm{CB} 1 \mathrm{p} 3$ was more similar in bacterial composition to Sapa Sp5p23 and Sp3p5 (Fig. 6)). In contrast, in terms of eukaryotic composition, CB1p3 was more similar to $\mathrm{CB} 1 \mathrm{p} 1$ and $\mathrm{CB} 1 \mathrm{p} 2$ while $\mathrm{CB} 1 \mathrm{p} 4$ was more similar to Sp9p234 (Fig. 6). Combined 
301 pitcher samples did not show higher bacterial diversity than single pitcher samples - within Cedarburg

302 samples the highest Inv Simpson, ACE and Shannon indices were for single pitcher CB1p4, and the

303 lowest in combined pitcher CB5p234. Within Sapa bacteria, combined sample Sp9p234 had some of the

304 lowest diversity values (Table 1).

305

306

307

308

309

310

311

312

313

314

315

316

317

318

319

320

321

322

323

324

325

326

\section{DISCUSSION}

This study presents the first detailed characterization of composition and diversity of both bacterial and eukaryotic organisms in S. purpurea pitchers within and between populations, as well as analysis of bacterial functions within pitcher communities compared with another freshwater environment.

\section{Bacterial Composition of Pitcher Plant Communities}

The dominance of Proteobacteria and Bacteriodetes in pitchers in both wetlands is similar to our preliminary genetic screening of these populations (Young, Sielicki \& Grothjan, 2018) and to previous studies of pitcher plant bacterial communities, where $\alpha, \beta$ and $\gamma$-Proteobacteria were dominant and Bacteroidetes and Firmicutes were common (Peterson et al., 2008; Koopman et al., 2010; Gray et al., 2012; Armitage, 2017; Canter et al., 2018). Bacterial classes were the same as those typically found in wetland soils (Zhang et al., 2017). However, the most common phylum, Saccharibacteria AT (formerly TM7), is known in wetlands, soil and aquatic habitats (Hugenholtz et al., 2001), but has previously been reported only in very low abundance in pitcher plants (Morales et al., 2006; Krieger \& Kourtev, 2012). The common families Sphingomonodaceae, Rhodospirillaceae, Oxalobacteraceae and many of the most abundant genera (Pedobacter, Aquitalea, Sphingomonas, Rickettsiella, Azospirillum) are common with previous reports for pitcher communities (Gray et al., 2012; Northrop et al., 2017; Canter et al., 2018; Young, Sielicki \& Grothjan, 2018). 
327

328

329

330

331

332

333

334

335

336

337

338

339

340

341

342

343

344

345

346

347

348

349

350

351

352

\section{Eukaryotic Composition of Pitcher Plant Communities}

Most of the eukaryotic diversity identified in the pitchers was from taxa defined as food web inhabitants rather than prey, confirming many groups known to play roles in the $S$. purpurea food web (e.g. Kneitel \& Miller, 2002; Mouquet et al., 2008; Adlassnig, Peroutka \& Lendl, 2011). Typically important eukaryotic taxa in S. purpurea food web models, which were not identified from DNA sequencing, include Wyeomyia smithii, Metriocnemus knabi and Habrotrocha rosa (Mouquet et al., 2008). Previous pitcher plant surveys also have shown absence of eukaryotic groups including arachnids or algae (Cresswell, 1991; Gebühr et al., 2006). However, one might expect to encounter the key rotifer, midge and mosquito larvae predators within the pitchers sampled. Alternative chironomid (Acricotopus), rotifer (Adineta vaga) and Culicidae mosquito taxa were identified (Table S2). Identifications may relate to limited taxon representation in the SILVA database, though SILVA is still a robust option (Balvočiūtè \& Huson, 2017). Identification of the typically sub-tropical mosquito Aedes aegypti also casts doubt on some genus-level identification. Manual sequence BLAST searches did not yield matches to Wyeomyia, Metriocnemus or Habtrotrocha. Lack of these taxa does raise the question, how common is it for communities in new and maturing pitchers to lack commonly regarded 'keystone species' and how soon do pitchers typically gain these organisms?

While some expected taxa were missing, this sequencing identified an impressive and previously under-appreciated number of different ciliate, mite, fungi and flagellate taxa in pitcher communities. Mite dominance has been noted with sequencing approaches in Sarracenia alata and Nepenthes (Bittleston et al., 2016; Satler, Zellmer \& Carstens, 2016) and in inquiline communities of bromeliads (Pešić, et al., 2016). Bactivorous protozoa including flagellates and ciliates are well-documented within S. purpurea (Hegner, 1926; TerHorst, 2001; Miller \& Kneitel, 2005; Miller \& TerHorst, 2012). Dominance of Colpoda species, which were found in both wetlands, and Tetrahymena sp., which was only found in Sapa, has also been reported in pitcher plants (Rojo-Herguedas \& Olmo, 1999; TerHorst, 2011) and dominant ciliates are known to influence community composition (Paisie, Miller \& Mason, 2014; Canter et al., 2018). The large diversity of ciliates encountered could be related to low abundance or absence in 
353 some pitchers of mosquito larvae taxa (including $W$. smithii), which typically predate ciliates and other

354 protozoa in pitchers; CB1p4 had the highest ciliate sequence count and lacked all mosquito taxa. The

355 ciliate dominance and high taxonomic diversity in pitcher plants identified, especially

356 Oligohymenophorea is more comparable to communities hosted by bromeliads (Simão et al., 2017).

357 Algae have previously been identified in Cedarburg Bog pitcher populations (Young, Sielicki \&

358 Grothjan, 2018) but in this study only a few algal 18S rRNA sequences were identified, and none of them

359 typically photoautotrophic taxa, in contrast to algae identified in Nepenthes pitchers (Bittleston et al.,

360 2016). While algal presence can vary in pitchers (Gebühr et al., 2006), 18S rRNA primer bias may have

361 limited identification of algal taxa (Bradley, Pinto \& Guest, 2016). Fungi have morphologically been

362 identified within pitchers (Lindquist, 1975; Adlassnig, Peroutka \& Lendl, 2011), and this study identified

363 representatives of all major fungal phyla, including Chytrids (Table S2). Use of 28S rRNA sequencing

364 targets also identified dominant fungi among OTUs from S. alata populations, though most of the 15

365 fungal OTUs named were Ascomycetes, and none were Chytrids (Satler, Zellmer \& Carstens, 2016); a

366 wider range of fungal groups were identified in S. purpurea using fungal PCR targets (Boynton, 2012).

367

368

369

370

371

372

373

374

375

376

377

378

\section{Bacterial Differences Within and Between Populations}

While there were some bacterial families present in only one wetland (Fig. 2) the most abundant taxa were common to both wetlands. Bacterial composition can be very similar between pitchers, e.g., $\mathrm{CBp} 1$ and $\mathrm{CBp} 2$ on the same plant, but other pitchers on the same plant (CB1p3, CB1p4) showed different composition. Even within a plant, changes in pitcher community composition over time are likely related to pitcher age, capture of particular prey organisms and microbial colonization (Armitage, 2017). Pitcher age was not specifically controlled for in this study, though similar-looking pitchers were selected. Some similar and some very different bacterial composition between pitchers on just a single (CB1) plant illustrates the very variable colonization of pitchers.

Differences between the two bacterial populations may relate to habitat. The bacterial family Kiloniellaceae, only found in Sapa pitchers, has a preference for low pH (Wiese et al., 2009), so the lower 
379

380

381

382

383

384

385

386

387

388

389

390

391

392

393

394

395

396

397

398

399

400

401

402

403

404

groundwater $\mathrm{pH}$ in Sapa (Bott, Meyer \& Young, 2008) may provide better surrounding bog habitat as a source to colonize pitchers. In Sapa, the greater presence of the human pathogen family Neisseriaceae is intriguing, but they can also be aquatic (Chu et al., 2018). Higher abundance of Rhizobiales and Nitrosomonadaceae in Cedarburg may reflect more active microbial $\mathrm{N}$ cycling within pitchers in this habitat, which has more limiting N in wetland soils than in Sapa (Bott, Meyer \& Young, 2008). Habitat differences are known to enrich particular bacterial taxa within pitchers (Gray et al., 2012; Krieger \& Kourtev, 2012). Detailed analysis of the known habitats and functions of the bacterial taxa found in pitchers was recently published (Young, Sielicki \& Grothjan, 2018).

\section{Eukaryotic Differences Within and Between Populations}

The variation in Eukaryotic community composition between pitchers was greater than for bacteria, with differences in mosquito, millipede and ant taxa, and ciliates and fungi, driving NMDS separation between populations (Fig. 5). Wetland differences could relate to different surrounding plant community composition, and bog pH conditions between the two habitats (Bott, Meyer \& Young, 2008). While both populations had mosquito, ciliate and fungal taxa, the family or genus representation often differed, suggesting different pools of species to colonize pitchers within the two wetlands. Localized air currents may also affect recruitment into pitchers; Sapa has a denser canopy and more physical obstacles between pitchers than the more open Cedarburg Bog, and morphologically, Sapa pitchers also have narrower openings which may reduce prey capture ( Bott, Meyer \& Young, 2008). Habitat and pitcher morphology may contribute to larger differences between Sapa compared with Cedarburg samples (Figs 4,5 ) and to greater randomness of colonization by larger eukaryotes through prey capture or incidental introduction. Dominance of particular taxa may be attributable to DNA from larger multicellular individuals with many copies of the $18 \mathrm{~S}$ rRNA gene. For example, high Diplopoda sequence counts (e.g., CB1p1) could have resulted from a single millipede within a pitcher, and presence of ant DNA (Formicidae, Table S21) would depend on rarer ant capture. Within the 5 Sapa samples, differences in presence/abundance of the freshwater ciliates Tetrahymenidae, soil fungi, Chytrids and Acari (mites) 
405

406

407

408

409

410

411

412

413

414

415

416

417

418

419

420

421

422

423

424

425

426

427

428

429

430

taxa, suggest that recruitment into pitchers may be rather stochastic. Many mites are parasitic on insects

(Berghoff et al. 2009) and may be introduced with insect prey. DNA from Basidiomycete,

Glomeromycota and Ascomycete taxa, present in the wetlands as plant saprophytes or symbionts, may be incidentally introduced as wind-born spores or fragments.

\section{Bacteria-Eukaryote Interactions}

Eukaryotic composition, which differed between the two wetlands, including mosquito, millipede ant, ciliate and fungal taxa, may contribute to differences in bacterial recruitment to individual pitchers. However, while samples CB1p1 and CB1p2 showed both similar bacterial and eukaryotic composition, there was no clear evidence across all samples that bacterial composition closely follows eukaryotic composition, which suggests that bacterial colonization of pitchers may not be solely related to prey capture. Colonization of more diverse bacterial communities was also not dependent on more diverse eukaryotic representation, as Sapa samples showed higher eukaryotic diversity but lower bacterial diversity than Cedarburg samples. Early studies assumed that the largest source of bacteria within pitchers is transferred from prey (Hepburn \& St John, 1927), and there is good experimental evidence that presence of invertebrate or protist taxa influences bacterial composition (Peterson et al., 2008; Paisie et al., 2014; Canter et al., 2018). However, contributions of bacterial taxa from prey versus wind, rain or other non-prey sources needs to be more rigorously examined.

\section{Bacterial Taxonomic Diversity}

The microbial diversity calculated as Shannon diversity index can be directly compared with other studies. Shannon bacterial diversity in both populations $(2.72-8.15)$ were generally higher than the values $(2.17-2.47)$ for S. purpurea based on T-RFLP analysis (Peterson et al., 2008) and other inquiline communities based on DGGE (Ponnusamy et al., 2008), but more similar to values using Illumina sequencing reported in S. purpurea (Paisie, Miller \& Mason, 2014; Bittleston et al., 2018) and the pitcher plant Darlingtonia californica (Sarraceniaceae) (Armitage, 2017). Shannon diversity of bacteria in these 
431 small volume pitchers was within the ranges reported for freshwater habitats (Wang et al., 2012; Banerji

432 et al., 2018). Higher Chao1 richness in both populations (5083-22188) than previous reports for $S$.

433 purpurea ( 200 - 500) (Paisie, Miller \& Mason, 2014), suggesting good sequence coverage, high

434 diversity and representation of relatively rare bacterial taxa. The higher bacterial richness in Cedarburg

435 than Sapa could be related to bog habitat conditions and plant composition (Bott, Meyer \& Young, 2008).

436

437

Eukaryotic Taxonomic Diversity

The number of Eukaryotic OTUs observed in this study are higher than seen in S. alata with genetic sequencing of 28S rRNA gene (Satler, Zellmer \& Carstens, 2016) and 18S rRNA analysis in $S$. purpurea (Bittleston et al., 2018), and clearly much higher than possible with microscope-based analyses

441 (Kneitel \& Miller, 2002; Gray, 2012). S. purpurea hosts the highest diversity of eukaryotic inquilines of

442 all pitcher plants (e.g. 10 species in Darlingtonia california vs 165 in S. purpurea (Adlassnig, Peroutka \&

443 Lendl, 2011)), which may contribute to the higher genetic sequence diversity than in previous studies.

444 This study contributes much higher detail of the diversity of the known types of organisms that are present and playing roles in the pitcher plant food web.

446

Bacterial Functions in Pitcher Communities

Differences in taxonomic composition between wetlands were minor relative to the comparison

freshwater community, and the overlap between wetlands visualized in PCoA plots suggests the two populations supported similar communities and metabolic functions. Known bacterial functions in $S$. purpurea, mostly relate to prey degradation including extracellular hydrolytic enzyme activity of proteases, chitinases, phophatases, and cellulases as well as nutrient transformations including nitrate reduction, denitrification, and photosynthesis (Young, Sielicki \& Grothjan, 2018). Many taxa identified in this study (Table S1), are known to have cellulolytic, chitinolytic and other hydrolytic capabilities, reviewed by Young, Sielicki \& Grothjan (2018). The amino-acid and carbohydrate and glycerolipid 
457 processes in pitchers artificially enriched with insect prey additions (Northrop et al., 2017), suggesting

458 these are key functions for detrital breakdown in pitcher communities. Predictions from PICRUSt

459 identified more metabolism of specific amino acids including tryptophan, alanine, and lysine, relative to

460 the wastewater outgroup. The high frequency genus, Duganella, identified in all pitchers (Table S1) is

461 known to produce anti-microbial compounds directly using tryptophan (Choi et al., 2015). More detailed

462 examination of amino acid transformations in pitcher plants is warranted, particularly if plants can access

463 amino N (Karagatzides, Butler \& Ellison, 2009). Functional vectors also suggested that relative to the

464 freshwater comparison communities, photosynthesis may be a minor contributor to food web C

465 acquisition in these detrital food webs, which gain organic $\mathrm{C}$ from insect prey.

466

467

468

469

470

471

472

473

474

475

476

477

478

479

480

481

\section{SYNTHESIS AND CONCLUSIONS}

This study provides the first detailed genetic analysis of eukaryotic organisms in the model food web of $S$. purpurea pitchers using mass sequencing, reporting diversity of known key taxonomic groups especially showing a remarkable and previously under-appreciated diversity of ciliates, fungi and mites in these communities. The study also compares eukaryotic and prokaryotic composition of the same pitcher samples, indicating the more stochastic nature of eukaryotic recruitment and suggesting that bacterial recruitment is not entirely linked to eukaryotic prey capture. The comparison also indicates that despite some key bacterial taxa presence differences between pitchers, prey digestion functions in pitchers are relatively preserved or converge to achieve similar food web function. Hydrolytic enzyme activity regulation in pitcher plants was similar to that in other aquatic ecosystems (Young, Sielicki \& Grothjan, 2018), and the microbial diversity represented in these $20-30 \mathrm{ml}$ pitcher communities rivals that of larger aquatic ecosystems. Key emerging questions from this study include how recruitment of bacteria versus eukaryotes into pitchers is mediated.

\section{REFERENCES}


482

483

484

485

486

487

488

489

490

491

492

493

494

495

496

497

498

499

500

501

502

503

504

505

506

507

Abubucker S., Segata N., Goll J., Schubert AM., Izard J., Cantarel BL., Rodriguez-mueller B., Zucker J., Thiagarajan M., Schloss PD., Gevers D., Henrissat B., White O., Kelley ST., Methe B., Mitreva M., Huttenhower C. 2012. Metabolic Reconstruction for Metagenomic Data and Its Application to the Human Microbiome. PLoS Computational Biology 8:1-17. DOI: 10.1371/journal.pcbi.1002358.

Adlassnig W., Peroutka M., Lendl T. 2011. Traps of carnivorous pitcher plants as a habitat: composition of the fluid, biodiversity and mutualistic activities. Annals of Botany 107:181-94. DOI: $10.1093 / \mathrm{aob} / \mathrm{mcq} 238$.

Armitage DW. 2017. Linking the development and functioning of a carnivorous pitcher plant's microbial digestive community. The ISME Journal 11:2439.

Aronesty E. 2011. Command-line tools for processing biological sequencing data. http://code.google.com/p/ea-utils.

Baiser B., Buckley HL., Gotelli NJ., Ellison AM. 2013. Predicting food-web structure with metacommunity models. Oikos 122:492-506. DOI: 10.1111/j.1600-0706.2012.00005.x.

Balvočiūtė M., Huson DH. 2017. SILVA, RDP, Greengenes, NCBI and OTT — how do these taxonomies compare? BMC Genomics 18:1-8. DOI: 10.1186/s12864-017-3501-4.

Banerji A., Bagley M., Elk M., Pilgrim E., Martinson J., Santo Domingo J. 2018. Spatial and temporal dynamics of a freshwater eukaryotic plankton community revealed via 18S rRNA gene metabarcoding. Hydrobiologia 818:71-86. DOI: 10.1007/s10750-018-3593-0.

Berghoff SM., Wurst E., Ebermann E., Sendova-Franks AB., Rettenmeyer CW., Franks NR. 2009. Symbionts of societies that dission: Mites as guests or parasites of army ants. Ecological Entomology 34:684-695. DOI: 10.1111/j.1365-2311.2009.01125.x

Bittleston LS., Baker CCM., Strominger LB., Pringle A., Pierce NE. 2016. Metabarcoding as a tool for investigating arthropod diversity in Nepenthes pitcher plants. Austral Ecology 41:120-132. DOI: 10.1111/aec.12271.

Bittleston LS., Wolock CJ., Yahya BE., Chan XY., Chan KG., Pierce NE., Pringle A. 2018. Convergence between the microcosms of Southeast Asian and North American pitcher plants. eLife 7:1-19. DOI: 
508

509

510

511

512

513

514

515

516

517

518

519

520

521

522

523

524

525

526

527

528

529

530

531

532

533

10.7554/eLife.36741.

Bledzki LA., Ellison AM. 1998. Population growth and production of Habrotrocha rosa Donner

(Rotifera: Bdelloidea) and its contribution to the nothern pitcher plant, Sarracenia purpurea L. (Sarraceniaceae). Hydrobiologia 385:193-200.

Bott T., Meyer GA., Young EB. 2008. Nutrient limitation and morphological plasticity of the carnivorous pitcher plant Sarracenia purpurea in contrasting wetland environments. The New Phytologist 180:631-641. DOI: 10.1111/j.1469-8137.2008.02575.x.

Boynton P. 2012. Ecological patterns and processes in Sarracenia carnivorous pitcher plant fungi. Doctoral Dissertation, Harvard Univeristy.

Bradley IM., Pinto AJ., Guest JS. 2016. Design and Evaluation of Illumina MiSeq-Compatible, 18S rRNA Gene-Specific Primers for Improved Characterization of Mixed Phototrophic Communities. Applied and Environmental Microbiology 82:5878-5891. DOI: 10.1128/AEM.01630-16.Editor.

Buckley HL., Miller TE., Ellison AM., Gotelli NJ. 2003. Reverse latitudinal trends in species richness of pitcher-plant food webs. Ecology Letters 6:825-829. DOI: 10.1046/j.1461-0248.2003.00504.x.

Canter EJ., Empeler CC., Pastore AI., Miller TE., Mason OU. 2018. Predator identity more than predator richness structures aquatic microbial assemblages in Sarracenia purpurea leaves. Ecology 99:652660. DOI: $10.1002 /$ ecy.2128.

Caporaso JG., Bittinger K., Bushman FD., Desantis TZ., Andersen GL., Knight R. 2010. PyNAST: A flexible tool for aligning sequences to a template alignment. Bioinformatics 26:266-267. DOI: 10.1093/bioinformatics/btp636.

Chao A. 1984. Nonparametric Estimation of the Number of Classes in a Population. Scandinavian Journal of Statistics 11:265-270.

Choi SY., Kim S., Lyuck S., Kim SB., Mitchell RJ. 2015. High-level production of violacein by the newly isolated Duganella violaceinigra str. NI28 and its impact on Staphylococcus aureus. Scientific Reports 5:1-12. DOI: 10.1038/srep15598.

Chu BTT., Petrovich ML., Chaudhary A., Wright D., Murphy B., Wells G., Poretsky R. 2018. 
534 Metagenomics reveals the impact of wastewater treatment plants on the dispersal of microorganisms 535 and genes in aquatic sediments. Applied and Environmental Microbiology 84:1-31. DOI:

$536 \quad$ 10.1128/AEM.02168-17.

537 Claesson MJ., Wang Q., O’Sullivan O., Greene-Diniz R., Cole JR., Ross RP., O’Toole PW. 2010.

538 Comparison of two next-generation sequencing technologies for resolving highly complex

539 microbiota composition using tandem variable 16S rRNA gene regions. Nucleic Acids Research

$540 \quad 38:$ e200. DOI: $10.1093 /$ nar/gkq873.

541 Cresswell J. 1991. Capture rates and composition of insect prey of the pitcher plant Sarracenia purpurea. $542 \quad$ American Midland Naturalist 125:1-9.

543 Dethlefsen L., Huse SM., Sogin ML., Relman DA. 2008. Exploring microbial diversity and taxonomy

$544 \quad$ using SSU rRNA hypervariable tag sequencing. PLoS Genetics 4. DOI:

$545 \quad$ 10.1371/journal.pgen.1000255.

546 Edgar RC. 2010. Search and clustering orders of magnitude faster than BLAST. Bioinformatics 26:2460-

547 2461. DOI: 10.1093/bioinformatics/btq461.

548 Edgar RC., Haas BJ., Clemente JC., Quince C., Knight R. 2011. UCHIME improves sensitivity and speed 549 of chimera detection. Bioinformatics 27:2194-2200. DOI: 10.1093/bioinformatics/btr381.

550 Ellison A., Adamec L. 2018. Carnivorous Plants: Physiology, Ecology, and Evolution. Oxford University $551 \quad$ Press, Oxford, UK.

552 Gebühr C., Pohlon E., Schmidt AR., Küsel K. 2006. Development of microalgae communities in the 553 Phytotelmata of allochthonous populations of Sarracenia purpurea (Sarraceniaceae). Plant Biology 554 8:849-60. DOI: 10.1055/s-2006-924474.

555 Gotelli N., Ellison A. 2002. Nitrogen deposition and extinction risk in the northern pitcher plant, $556 \quad$ Sarracenia purpurea. Ecology 83:2758-2765.

557 Gotelli NJ., Ellison AM. 2006. Food-web models predict species abundances in response to habitat 558 change. PLoS Biology 4:1869-1873. DOI: 10.1371/journal.pbio.0040324.

559 Gray SM. 2012. Succession in the aquatic Sarracenia purpurea community: deterministic or driven by 
contingency? Aquatic Ecology 46:487-499. DOI: 10.1007/s10452-012-9417-9.

561 Gray SM., Akob DM., Green SJ., Kostka JE. 2012. The bacterial composition within the Sarracenia

562 purpurea model system: local scale differences and the relationship with the other members of the

563 food web. PLoS one 7:e50969. DOI: 10.1371/journal.pone.0050969.

564 Haas BJ., Gevers D., Earl AM., Feldgarden M., Ward D V., Giannoukos G., Ciulla D., Tabbaa D.,

565 Highlander SK., Desantis TZ., Sodergren E., Methe B., Human T., Consortium M., Petrosino JF.,

566 Knight R., Birren BW. 2011. Chimeric 16S rRNA sequence formation and detection in Sanger and

567 454-pyrosequenced PCR amplicons. Genome Research 21:494-504. DOI:

$568 \quad$ 10.1101/gr.112730.110.Freely.

569 Hammer Ø., Harper DA., Ryan P. 2001. PAST: Paleontological Statistics Software Package for

$570 \quad$ Education and Data Analysis. Palaeontologia Electronica 4(1):1-9. DOI:

571 10.1016/j.bcp.2008.05.025.

572

Hegner R. 1926. The Protozoa of the Pitcher Plant, Sarracenia purpurea. The Biological Bulletin 50:271573276.

574 Hepburn JS., St John EQ. 1927. A bacteriological study of the pitcher liquor of the Sarraceniaceae.

$575 \quad$ Transactions of the Wagner Free Institute of Science of Philadelphia 11:75-83.

576 Hugenholtz P., Tyson GW., Webb RI., Wagner M., Blackall LL., Wagner AM. 2001. Investigation of

577 Candidate Division TM7, a Recently Recognized Major Lineage of the Domain Bacteria with No

578 Known Pure-Culture Representatives. Applied and Environmental Microbiology 67:411-419. DOI:

$579 \quad$ 10.1128/AEM.67.1.411.

580 Karagatzides JD., Butler JL., Ellison AM. 2009. The pitcher plant Sarracenia purpurea can directly

581 acquire organic nitrogen and short-circuit the inorganic nitrogen cycle. PLoS one 4:1-9. DOI:

$582 \quad$ 10.1371/journal.pone.0006164.

583 Kneitel J., Miller T. 2002. Resource and top-predator regulation in the pitcher plant (Sarracenia 584 purpurea) inquiline community. Ecology 83:680-688.

585 Koopman M., Carstens B. 2011. The Microbial Phyllogeography of the Carnivorous Plant Sarracenia 
alata. Microbial Ecology 61:750-758. DOI: 10.1007/s00248-011-9832-9.

587 Koopman MM., Fuselier DM., Hird S., Carstens BC. 2010. The carnivorous pale pitcher plant harbors

588 diverse, distinct, and time-dependent bacterial communities. Applied and Environmental

589 Microbiology 76:1851-60. DOI: 10.1128/AEM.02440-09.

590 Kozich JJ., Westcott SL., Baxter NT., Highlander SK., Schloss PD. 2013. Development of a Dual-Index

591 Sequencing Strategy and Curation Pipeline for Analyzing Amplicon Sequence Data on the MiSeq.

592 Applied and Environmental Microbiology 79:5112-5120. DOI: 10.1128/AEM.01043-13.

593 Krieger JR., Kourtev PS. 2012. Bacterial diversity in three distinct sub-habitats within the pitchers of the

594 northern pitcher plant, Sarracenia purpurea. FEMS Microbiology Ecology 79:555-567. DOI:

$595 \quad 10.1111 /$ j.1574-6941.2011.01240.x.

596

Langille MGI., Zaneveld J., Caporaso JG., McDonald D., Knights D., Reyes JA., Clemente JC.,

597 Burkepile DE., Vega Thurber RL., Knight R., Beiko RG., Huttenhower C. 2013. Predictive

598 functional profiling of microbial communities using 16S rRNA marker gene sequences. Nature

599 Biotechnology 31:814-821. DOI: 10.1038/nbt.2676.

600 Lau MK., Baiser B., Gotelli NJ., Ellison AM. 2018. Regime shifts, alternative states and hysteresis in the 601 Sarracenia microecosystem. Ecological Modelling 382:1-27. DOI: 10.1101/087296.

602 Lindquist J. 1975. Bacteriological and ecological observations of the Northern Pitcher Plant, Sarracenia 603 purpurea L. Doctoral Dissertation, University of Wisconsin-Madison.

604 Lozupone C., Lladser ME., Knights D., Stombaugh J., Knight R. 2011. UniFrac: An effective distance 605 metric for microbial community comparison. ISME Journal 5:169-172. DOI:

$606 \quad 10.1038 /$ ismej.2010.133.

607 Luciano CS., Newell SJ. 2017. Effects of prey, pitcher age, and microbes on acid phosphatase activity in 608 fluid from pitchers of Sarracenia purpurea (Sarraceniaceae). PLoS ONE 12:1-17. DOI:

$609 \quad$ 10.1371/journal.pone.0181252.

610 Marron AO., Akam M., Walker G. 2013. A duplex PCR-based assay for measuring the amount of 611 bacterial contamination in a nucleic acid extract from a culture of free-living protists. PLoS One 
613 Miller TE., Kneitel JM. 2005. Inquiline communities in pitcher plants as a prototypical metacommunity.

614 In: Holyoak M, Leibold MA, Holt RD, editors. Metacommunities: spatial dynamics and ecological 615 communities. University of Chicago Press, Chicago, USA. 122-145.

616 Miller TE., TerHorst CP. 2012. Testing successional hypotheses of stability, heterogeneity, and diversity 617 in pitcher-plant inquiline communities. Oecologia 170:243-251. DOI: 10.1007/s00442-012-2292-1. 618 Mouquet N., Daufresne T., Gray SM., Miller TE. 2008. Modelling the relationship between a pitcher 619 plant (Sarracenia purpurea) and its phytotelma community: mutualism or parasitism? Functional Ecology 22:728-737. DOI: 10.1111/j.1365-2435.2008.01421.x.

Northrop AC., Brooks RK., Ellison AM., Gotelli NJ., Ballif BA. 2017. Environmental proteomics reveals taxonomic and functional changes in an enriched aquatic ecosystem. Ecosphere 8. DOI: 10.1002/ecs2.1954.

Paisie TK., Miller TE., Mason OU. 2014. Effects of a Ciliate Protozoa Predator on Microbial Communities in Pitcher Plant (Sarracenia purpurea) Leaves. PLoS One 9:e113384. DOI: 10.1371/journal.pone.0113384.

Pešić, V., Zawal A., Piccoli G., Gonçalves A. 2016. New records of water mites (Acari, Hydrachnidia) from bromeliad phytotelmata in Brazilian Atlantic rainforest, with description of one new species. Systematic and Applied Acarology 21:537-544.

Peterson CN., Day S., Wolfe BE., Ellison AM., Kolter R., Pringle A. 2008. A keystone predator controls bacterial diversity in the pitcher-plant (Sarracenia purpurea) microecosystem. Environmental Microbiology 10:2257-2266. DOI: 10.1111/j.1462-2920.2008.01648.x.

Ponnusamy L., Xu N., Stav G., Wesson DM., Schal C., Apperson CS. 2008. Diversity of bacterial communities in container habitats of mosquitoes. Microbial Ecology 56:593-603. DOI: 10.1007/s00248-008-9379-6.

Price MN., Dehal PS., Arkin AP. 2010. FastTree 2 - Approximately Maximum-Likelihood Trees for Large Alignments. PLoS ONE 5:1-10. DOI: 10.1371/journal.pone.0009490. 
638 Pruesse E., Quast C., Knittel K., Fuchs BM., Ludwig W., Peplies J., Glöckner FO. 2007. SILVA: A 639 comprehensive online resource for quality checked and aligned ribosomal RNA sequence data 640 compatible with ARB. Nucleic Acids Research 35:7188-7196. DOI: 10.1093/nar/gkm864.

641 Quast C., Pruesse E., Yilmaz P., Gerken J., Schweer T., Glo FO., Yarza P. 2013. The SILVA ribosomal 642 RNA gene database project : improved data processing and web-based tools. Nucleic Acids $643 \quad$ Research 41:590-596. DOI: 10.1093/nar/gks1219.

644 Rojo-Herguedas I., Olmo J. 1999. The ciliated protozoa of the pitcher plant Sarracenia purpurea. Acta 645 protozoologica $2(38)$.

646 Satler JD., Zellmer AJ., Carstens BC. 2016. Biogeographic barriers drive co-diversification within 647 associated eukaryotes of the Sarracenia alata pitcher plant system. PeerJ 4:e1576. DOI: 10.7717/peerj. 1576 .

Simão TLL., Giongo A., Gano KA., Davis-richardson AG., Brown CT., Fagen JR., Triplett EW., Dias R., Mondin CA., Renata M., Eizirik E., Utz LRP. 2017. Characterization of ciliate diversity in

652 bromeliad tank waters from the Brazilian Atlantic Forest. European Journal of Protistology 61:359365. DOI: 10.1016/j.ejop.2017.05.005.

Siragusa AJ., Swenson JE., Casamatta DA. 2007. Culturable bacteria present in the fluid of the hooded654 655 pitcher plant Sarracenia minor based on 16S rDNA gene sequence data. Microbial Ecology 54:32431. DOI: $10.1007 / \mathrm{s} 00248-006-9205-\mathrm{y}$.

TerHorst CP. 2011. Experimental evolution of protozoan traits in response to interspecific competition. Journal of Evolutionary Biology 24:36-46. DOI: 10.1111/j.1420-9101.2010.02140.x.

Wang Y., Sheng HF., He Y., Wu JY., Jiang YX., Tam NFY., Zhou HW. 2012. Comparison of the levels of bacterial diversity in freshwater, intertidal wetland, and marine sediments by using millions of illumina tags. Applied and Environmental Microbiology 78:8264-8271. DOI: 10.1128/AEM.0182112.

Whitman RL., Byers SE., Shively DA., Ferguson DM., Byappanahalli M. 2005. Occurrence and growth 663 characteristics of Escherichia coli and enterococci within the accumulated fluid of the northern 
664 pitcher plant (Sarracenia purpurea L.). Canadian Journal of Microbiology 51:1027-1037. DOI: $665 \quad 10.1139 /$ W05-091.

666 Wiese J., Thiel V., Gärtner A., Schmaljohann R., Imhoff JF. 2009. Kiloniella laminariae gen. nov., sp. 667 nov., an alphaproteobacterium from the marine macroalga Laminaria saccharina. International 668 Journal of Systematic and Evolutionary Microbiology 59:350-356. DOI: 10.1099/ijs.0.001651-0. 669 Xiao L., Young EB., Grothjan JJ., Lyon S., Zhang H., He Z. 2015. Wastewater treatment and microbial 670 communities in an integrated photo-bioelectrochemical system affected by different wastewater 671 algal inocula. Algal Research 12:446-454. DOI: 10.1016/j.algal.2015.10.008.

672 Young EB., Sielicki J., Grothjan JJ. 2018. Regulation of Hydrolytic Enzyme Activity in Aquatic 673 Microbial Communities Hosted by Carnivorous Pitcher Plants. Microbial Ecology 76:885-898. 674 DOI: $10.1007 / \mathrm{s} 00248-018-1187-\mathrm{z}$.

675 Zhang Z., Qu Y., Li S., Feng K., Wang S., Cai W. 2017. Soil bacterial quantification approaches coupling 676 with relative abundances reflecting the changes of taxa. Scientific Reports 7:1-11. DOI: $677 \quad 10.1038 / \mathrm{s} 41598-017-05260-w$. 
681 Figure 1. Genetic analysis of pitcher plant communities from two wetland populations, Cedarburg and 682 Sapa. Family phylotypes are based on 16S rRNA (bacterial) (A) and 18S rRNA (Eukaryotic) (B) taxa 683 identified from sequencing of total community DNA in pitcher fluid samples. Samples were collected 684 from Cedarburg (CB) and Sapa (Sp) wetlands from single plants (e.g. CB1-5) from individual pitchers 685 (e.g. p1-4) or combined pitchers (e.g. p234). Taxa with only one representative sequence were removed, 686 and any taxa representing $<0.01 \%$ of total in each sample were pooled as 'Other'. AT - ambiguous taxa, 687 IS - incertae sedis, unc. - uncultured.

Figure 2. Heatmap of family-level taxa based on 16S rRNA (A) and 18S rRNA (B) sequences isolated 690 from pitcher fluid samples (not-median adjusted). Color scale corresponds to the logarithmic transformation of the number of times a taxon was observed in each sample (green is lowest abundance, red is highest abundance). For bacteria in 5 samples from each population, taxa which were significantly higher in one population are shown with a p-value. Abbreviations are as for Fig. 1.

694

Figure 3. Composition of eukaryotic groups based on 18S rRNA sequences, showing most common Arthropod groups, ciliates, (ospithokont) flagellates, fungi, and other groups for each wetland population (A, B) (full details of taxa in each sample provided in Table S2). C. Using data pooled for all 10 samples, taxa representing $>1 \%$ of total sequences were scored as Food Web for aquatic taxa or those known to be pitcher inhabitants, Prey for non-aquatic Arthropods as likely captured prey, or Other for ambiguous taxa which may be present as incidentals (fungal spores blown into pitchers, taxa with unknown habitat or ecological role).

Figure 4. A. Pitcher bacterial communities visualized with PCoA for pitcher bacterial composition, and

B. Non-metric multidimensional scaling plot of PICRUSt predicted bacterial metabolic functions, in 5 
705 pitcher samples from each wetland, compared with 5 wastewater reference samples. Metabolic functions

706 plot shows 15 selected function categories as vectors separating the communities. Convex hulls overlay

707 the sample points for each group, showing overlap between the two wetland populations, which are

708 distinct from the wastewater communities. Vector name abbreviations relate to metabolic processes

709 associated with: b_Ala - b-Alanine, Lys - Lysine; Val_Leu-Ile - Valine-Leucine-Isoleucine; Trp -

710 Tryptophan; Gly_Ser_Thr-Glycine-Serine-Threonine; TCA_cyle; S_met - Sulphur metabolism;

711 Arg_Pro - Arginine-Proline; Glyc_lipid - glycerolipid; Sta_Suc - starch and sucrose; PS -

712 photosynthesis; PS_Pig - photosynthetic pigments; Glycan_biosyn - glycan biosynthesis; Cyst_Met -

713 cysteine-methionine; Phe_Tyr_Trp - Phenylalanine-Tyrosine-Trytophan.

714

715

Figure 5. A. PCoA score plot based on composition of eukaryotic taxa (18S rRNA sequences) identified in 5 pitcher samples from each wetland, compared with a curated freshwater EUKBASE database from

SILVA NR108. Convex hulls overlay the sample points for each group, showing overlap between the two samples, with correlation as the similarity measure.

721

722 Figure 6. Genetic diversity trees of samples from Cedarburg Bog and Sapa Bog based on 16S bacterial

723 (A) and $18 \mathrm{~S}$ eukaryotic (B) composition of taxa identified in 5 pitcher fluid samples from each

724 population. Bootstrap values for jackknife trees generated in QIIME were based on 100 iterations with a 725 minimum of $75 \%$ of the smallest sample sequence number. Cedarburg (CB) sample branches are black

726 while Sapa (Sp) sample branches are grey. Bacterial composition of samples is compared with pooled

727 wastewater outgroup (WW), and a curated freshwater EUKBASE database from SILVA. 


\section{Table $\mathbf{1}$ (on next page)}

Bacterial and eukaryotic diversity metric for two pitcher plant populations

Summary of diversity metrics for bacterial (top) and eukaryotic (bottom) analysis of 10 Sarracenia purpurea pitcher fluid samples. OTUs were defined by a $97 \%$ similarity. Means of values are shown for each wetland population, bolded and $p$ values when there were significant differences between populations. There were no significantly differences in $18 \mathrm{~S}$ data between wetlands. 
1 Table 1. Summary of diversity metrics for bacterial (top) and eukaryotic (bottom) analysis of 10

2 Sarracenia purpurea pitcher fluid samples. OTUs were defined by a $97 \%$ similarity. Means of values are

3 shown for each wetland population, bolded and p-values when there were significant differences

4 between populations. There were no significantly differences in $18 \mathrm{~S}$ data between wetlands.

\section{A. 165 Bacteria}

\begin{tabular}{|c|c|c|c|c|c|c|c|}
\hline & $\begin{array}{c}\text { Observed } \\
\text { OTUs }\end{array}$ & Chao1 & singletons & $\begin{array}{c}\text { Inv } \\
\text { Simpson }\end{array}$ & Shannon & ACE & $\begin{array}{c}\text { Goods } \\
\text { Coverage }\end{array}$ \\
\hline \multicolumn{8}{|l|}{ Cedarburg } \\
\hline CB1p1 & 2664 & 8098.5 & 1688 & 16.041 & 6.155 & 7679.8 & 0.9768 \\
\hline CB1p2 & 2923 & 10470.6 & 1993 & 17.389 & 6.446 & 9644.4 & 0.9589 \\
\hline CB1p3 & 4186 & 14820.2 & 2975 & 19.513 & 6.591 & 15283.1 & 0.9534 \\
\hline CB1p4 & 4326 & 22188.0 & 3434 & 43.579 & 8.149 & 23019.0 & 0.8585 \\
\hline \multirow[t]{2}{*}{ CB5p234 } & 2731 & 8500.3 & 1759 & 14.524 & 5.512 & 8081.4 & 0.9782 \\
\hline & 3366 & 12815.5 & 2369 & 22.209 & 6.571 & 12741.5 & 0.9452 \\
\hline \multicolumn{8}{|l|}{ Sapa } \\
\hline Sp3p2 & 1516 & 5153.3 & 1024 & 4.668 & 3.737 & 5153.6 & 0.9854 \\
\hline Sp3p4 & 1592 & 5089.0 & 1078 & 2.005 & 2.721 & 5348.8 & 0.9871 \\
\hline Sp3p5 & 1661 & 5083.7 & 1095 & 20.362 & 6.094 & 5333.2 & 0.9647 \\
\hline Sp5p23 & 2824 & 7185.5 & 1692 & 24.648 & 6.807 & 7260.7 & 0.9714 \\
\hline \multirow[t]{3}{*}{ Sp9p234 } & 1744 & 5164.5 & 1104 & 3.209 & 3.770 & 5043.8 & 0.9843 \\
\hline & 1867 & 5535.2 & 1199 & 10.978 & 4.626 & 5628.0 & 0.9786 \\
\hline & $p<0.025$ & $p<0.02$ & $p<0.015$ & & & $p<0.05$ & \\
\hline
\end{tabular}

\section{B. 18 S Eukaryotes}

\begin{tabular}{|c|c|c|c|c|c|c|c|}
\hline & $\begin{array}{c}\text { Observed } \\
\text { OTUs }\end{array}$ & Chao1 & singletons & $\begin{array}{c}\text { Inv } \\
\text { Simpson }\end{array}$ & Shannon & ACE & $\begin{array}{c}\text { Goods } \\
\text { Coverage }\end{array}$ \\
\hline \multicolumn{8}{|c|}{ Cedarburg } \\
\hline CB1p1 & 697 & 2282.5 & 475 & 2.341 & 2.280 & 2292.7 & 0.9951 \\
\hline CB1p2 & 978 & 3358.9 & 694 & 2.272 & 2.263 & 3558.4 & 0.9945 \\
\hline CB1p3 & 1494 & 6493.5 & 1114 & 3.007 & 2.782 & 6521.6 & 0.9904 \\
\hline CB1p4 & 573 & 1815.3 & 393 & 1.339 & 1.142 & 2040.3 & 0.9964 \\
\hline \multirow[t]{2}{*}{ CB5p234 } & 2010 & 15594.1 & 1657 & 11.559 & 5.298 & 14498.1 & 0.9500 \\
\hline & 1150 & 5908.9 & 867 & 4.104 & 2.753 & 5782.2 & 0.9853 \\
\hline \multicolumn{8}{|l|}{ Sapa } \\
\hline Sp3p2 & 1277 & 2854.5 & 711 & 8.945 & 4.556 & 2917.2 & 0.9924 \\
\hline Sp3p4 & 1023 & 3354.2 & 673 & 3.654 & 3.167 & 3234.3 & 0.9939 \\
\hline Sp3p5 & 1304 & 3408.4 & 779 & 4.762 & 4.102 & 3479.6 & 0.9904 \\
\hline Sp5p23 & 1248 & 3317.3 & 734 & 9.183 & 4.399 & 3231.0 & 0.9943 \\
\hline \multirow[t]{2}{*}{ Sp9p234 } & 861 & 3714.3 & 628 & 3.892 & 2.612 & 3700.6 & 0.9954 \\
\hline & 1143 & 3329.7 & 705 & 6.087 & 3.767 & 3312.5 & 0.9933 \\
\hline
\end{tabular}

6 


\section{Figure 1}

Bacterial and eukaryotic pitcher plant composition of samples in two populations

Genetic analysis of pitcher plant communities from two wetland populations, Cedarburg and

Sapa. Family phylotypes are based on 16S rRNA (bacterial) (A) and 18S rRNA (Eukaryotic) (B)

taxa identified from sequencing of total community DNA in pitcher fluid samples. Samples

were collected from Cedarburg (CB) and Sapa (Sp) wetlands from single plants (e.g. CB1-5)

from individual pitchers (e.g. p1-4) or combined pitchers (e.g. p234). Taxa with only one representative sequence were removed, and any taxa representing $<0.01 \%$ of total in each sample were pooled as 'Other'. AT - ambiguous taxa, IS - incertae sedis, unc. - uncultured. 


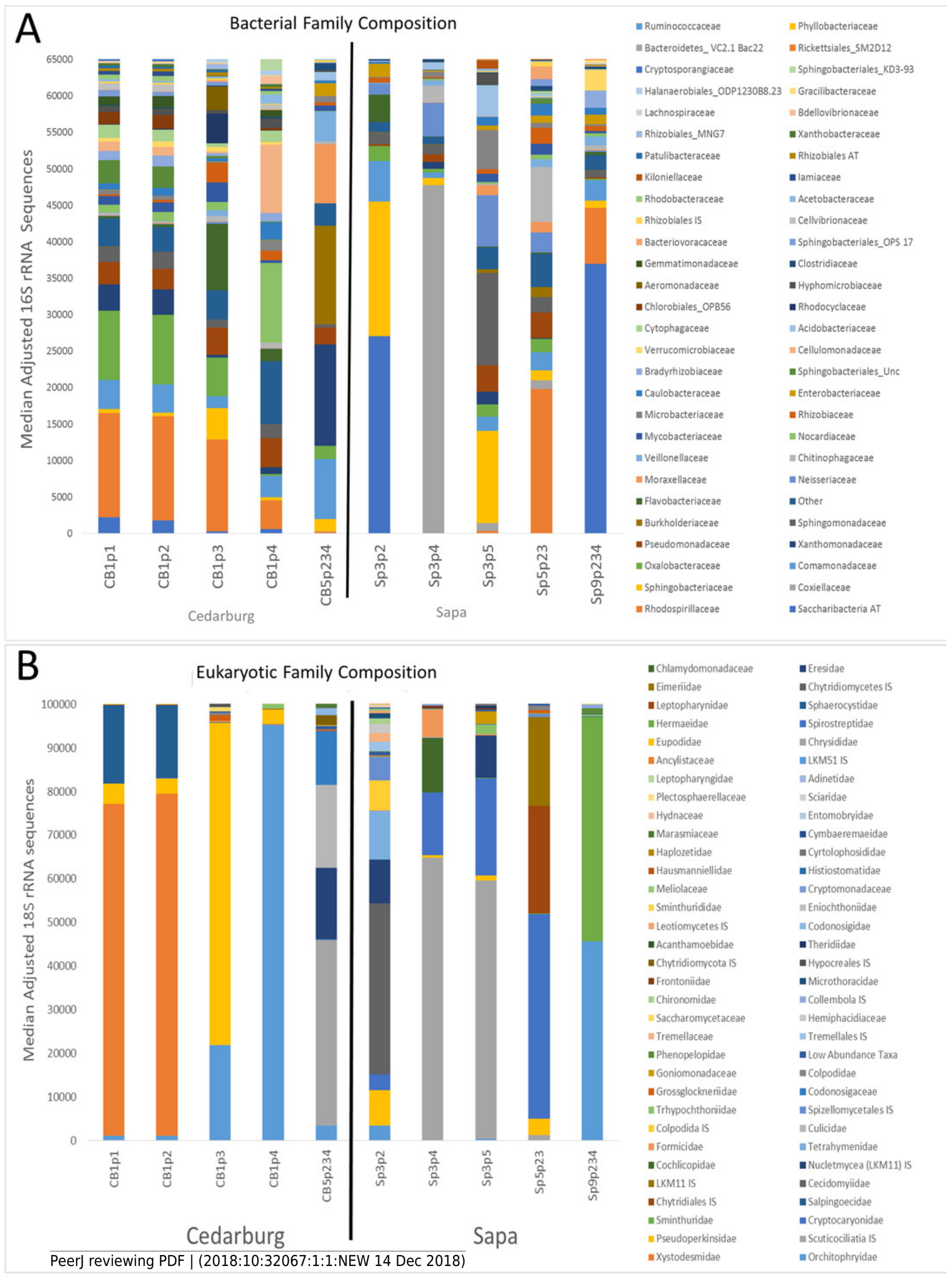




\section{Figure 2}

Heatmap of bacterial and eukaryotic families across the samples in two populations

Heatmap of family-level taxa based on 16S rRNA (A) and 18S rRNA (B) sequences isolated from pitcher fluid samples (not-median adjusted). Color scale corresponds to the logarithmic transformation of the number of times a taxon was observed in each sample (green is lowest abundance, red is highest abundance). For bacteria in 5 samples from each population, taxa which were significantly higher in one population are shown with a p-value. Abbreviations are as for Fig. 1. 


\begin{tabular}{|c|c|c|c|c|c|c|c|c|c|c|c|c|c|}
\hline \multicolumn{3}{|l|}{ BACTERIA } & \multicolumn{5}{|c|}{ Cedarburg } & \multirow[b]{2}{*}{ p-value } & \multicolumn{5}{|c|}{ Sapa } \\
\hline \multicolumn{2}{|l|}{ Phylum or Class } & Most Common Families & CB1p1 & CB1p2 & CB1p3 & CB1p4 & CB5p234 & & Sp3p2 & Sp3p4 & Sp3p5 & Sp5p23 & Sp9p234 \\
\hline \multicolumn{2}{|c|}{ Saccharibacteria } & Saccharibacteria AT & & & & & & & & & & & \\
\hline \multicolumn{2}{|c|}{ Gamma-Proteobacteria } & llaceae & & & & & & & & & & & \\
\hline \multicolumn{2}{|c|}{ Alpha-Proteobacteria } & ospirillaceae & & & & & & & & & & & \\
\hline \multicolumn{2}{|c|}{ Bacteroidetes } & gobacteriaceae & & & & & & & & & & & \\
\hline Beta-Proteobacte & & monadaceae & & & & & & & & & & & \\
\hline Beta-Proteobacte & & bacteraceae & & & & & & & & & & & \\
\hline Gamma-Proteoba & teria & tomonadaceae & & & & & & & & & & & \\
\hline Gamma-Proteoba & teria & tomonadaceae & & & & & & & & & & & \\
\hline Bacteroidetes & & gomonadaceae & & & & & & & & & & & \\
\hline Beta-Proteobacte & & olderiaceae & & & & & & & & & & & \\
\hline Flavobacteria & & bacteriaceae & & & & & & & & & & & \\
\hline Beta-Proteobacte & & eriaceae & & & & & & 0.02 & & & & & \\
\hline Gamma-Proteoba & teria & xellaceae & & & & & & & & & & & \\
\hline Bacteroidetes & & ophagaceae & & & & & & & & & & & \\
\hline Firmicutes & & nellaceae & & & & & & & & & & & \\
\hline & & Significant Families & & & & & & & & & & & \\
\hline Alpha-Proteobact & & bacteraceae & & & & & & 0.013 & & & & & \\
\hline Alpha-Proteobact & & iellaceae & & & & & & 0.035 & & & & & \\
\hline Alpha-Proteobact & & biales AT & & & & & & 0.029 & & & & & \\
\hline Alpha-Proteobact & & obacteraceae & & & & & & 0.039 & & & & & \\
\hline Actinobacteria & & dibacteraceae & & & & & & 0.04 & & & & & \\
\hline Oligoflexia & & flexaceae & & & & & & 0.031 & & & & & \\
\hline Beta-Proteobacte & & somonadaceae & & & & & & 0.006 & & & & & \\
\hline Gamma-Proteoba & teria & natiaceae & & & & & & 0.006 & & & & & \\
\hline Bacteroidetes & & spiraceae & & & & & & 0.047 & & & & & \\
\hline & & Log abundance & & & & & & & & & & & \\
\hline & & heatmap scale & 0 & & & & & 2.5 & & & & & 4.8 \\
\hline EUKARYOTE & & & & & Cedarbu & & & & & & Sapa & & \\
\hline Higher Taxon & Description & Most Common Families & CB1p1 & CB1p2 & CB1p3 & CB1p4 & CB5p234 & & Sp3p2 & Sp3p4 & Sp3p5 & Sp5p23 & Sp9p234 \\
\hline Ciliophora & ciliates & Orchitophryidae & & & & & & & & & & & \\
\hline Arthropoda & millipedes & Xystodesmidae & & & & & & & & & & & \\
\hline Ciliophora & ciliates & Scuticociliatia IS & & & & & & & & & & & \\
\hline Choanozoa & protists & Pseudoperkinsidae & & & & & & & & & & & \\
\hline Ciliophora & ciliates & Cryptocaryonidae & & & & & & & & & & & \\
\hline Arthropoda & springtails & Sminthuridae & & & & & & & & & & & \\
\hline Choanozoa & flagellates & Salpingoecidae & & & & & & & & & & & \\
\hline Chytridiomycota & aquatic fungi & Chytridiales IS & & & & & & & & & & & \\
\hline Arthropoda & gall midges & Cecidomyiidae & & & & & & & & & & & \\
\hline Cryptomycota & fungi & LKM11 IS & & & & & & & & & & & \\
\hline Mollusca & land snails & Cochlicopidae & & & & & & & & & & & \\
\hline Ciliophora & ciliates & Tetrahymenidae & & & & & & & & & & & \\
\hline Arthropoda & ants & Formicidae & & & & & & & & & & & \\
\hline Arthropoda & mosquitoes & Culicidae & & & & & & & & & & & \\
\hline Ciliophora & ciliates & Colpodida IS & & & & & & & & & & & \\
\hline Chytridiomycota & aquatic fungi & Spizellomycetales IS & & & & & & & & & & & \\
\hline Arthropoda & mites & Trhypochthoniidae & & & & & & & & & & & \\
\hline Choanozoa & flagellates & Codonosigaceae & & & & & & & & & & & \\
\hline Ciliophora & ciliates & Grossglockneriidae & & & & & & & & & & & \\
\hline Ciliophora & ciliates & Colpodidae & & & & & & & & & & & \\
\hline Cryptophyta & Cryptomonad: & Goniomonadaceae & & & & & & & & & & & \\
\hline Arthropoda & mites & Phenopelopidae & & & & & & & & & & & \\
\hline Basidiomycota & fungi & Tremellales is & & & & & & & & & & & \\
\hline Basidiomycota & fungi & Tremellaceae & & & & & & & & & & & \\
\hline Ascomycota & fungi & Hemiphacidiaceae & & & & & & & & & & & \\
\hline Ascomycota & yeasts & Saccharomycetaceae & & & & & & & & & & & \\
\hline Arthropoda & springtails & Collembola is & & & & & & & & & & & \\
\hline Arthropoda & midges & Chironomidae & & & & & & & & & & & \\
\hline Ciliophora & ciliates & Microthoracidae & & & & & & & & & & & \\
\hline Ciliophora & ciliates & Frontoniidae & & & & & & & & & & & \\
\hline Ascomycota & fungi & Hypocreales IS & & & & & & & & & & & \\
\hline Chytridiomycota & fungi & Chytridiomycota IS & & & & & & & & & & & \\
\hline
\end{tabular}




\section{Figure 3}

Pie chart of major eukaryotic groups and roles in microecosystem

Composition of eukaryotic groups based on $18 \mathrm{~S}$ rRNA sequences, showing most common Arthropod groups, ciliates, (ospithokont) flagellates, fungi, and other groups for each wetland population (A, B) (full details of taxa in each sample provided in Table S2). C. Using data pooled for all 10 samples, taxa representing $>1 \%$ of total sequences were scored as Food Web for aquatic taxa or those known to be pitcher inhabitants, Prey for non-aquatic Arthropods as likely captured prey, or Other for ambiguous taxa which may be present as incidentals (fungal spores blown into pitchers, taxa with unknown habitat or ecological role). 


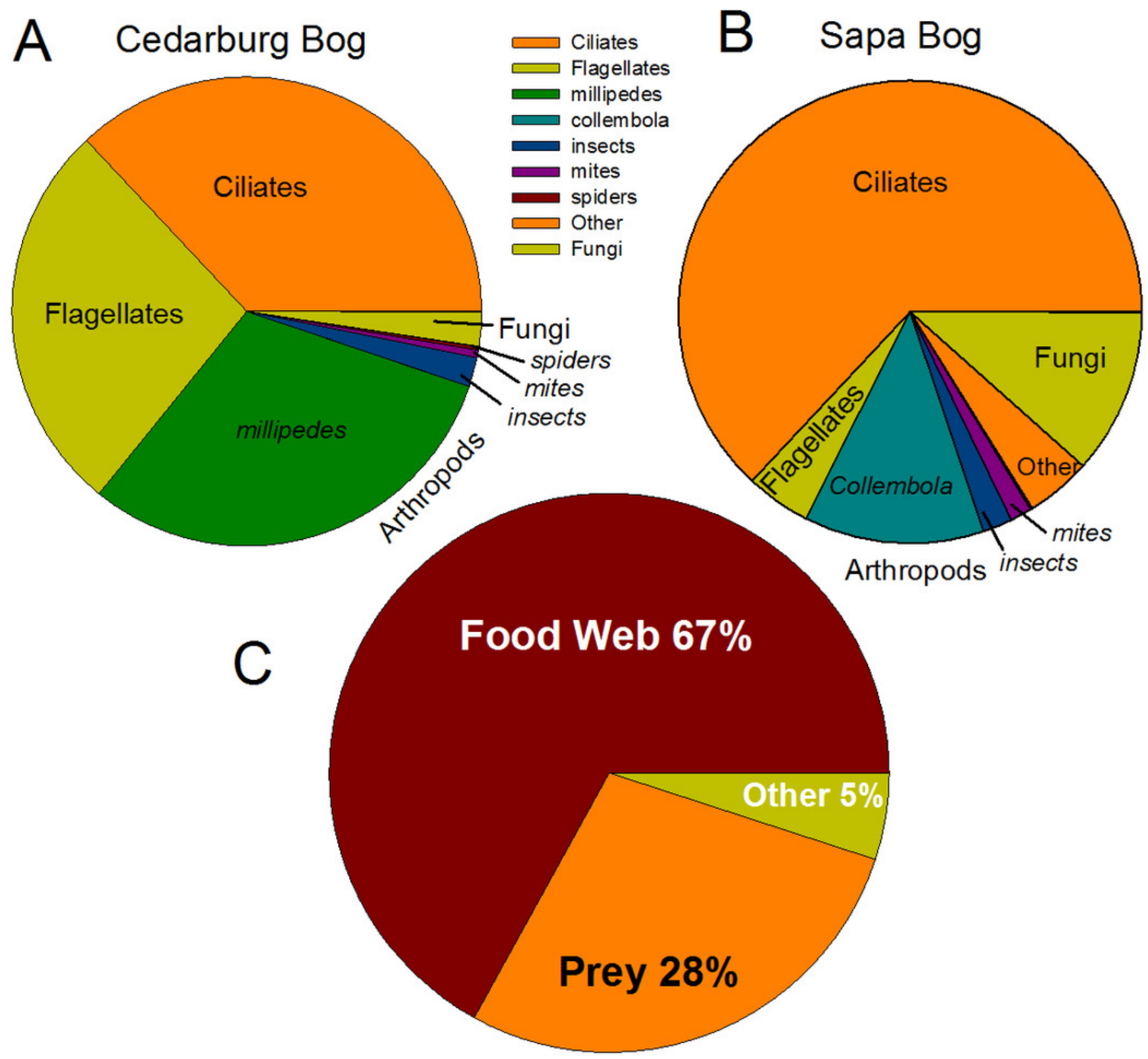




\section{Figure 4}

PCoA of pitcher plant bacterial composition and functions in two populations

A. Pitcher bacterial communities visualized with PCoA for pitcher bacterial composition, and

B. Non-metric multidimensional scaling plot of PICRUSt predicted bacterial metabolic functions, in 5 pitcher samples from each wetland, compared with 5 wastewater reference samples. Metabolic functions plot shows 15 selected function categories as vectors separating the communities. Convex hulls overlay the sample points for each group, showing overlap between the two wetland populations, which are distinct from the wastewater communities. Vector name abbreviations relate to metabolic processes associated with: b_Ala - b-Alanine, Lys - Lysine; Val_Leu-Ile - Valine-Leucine-Isoleucine; Trp - Tryptophan; Gly_Ser_Thr - Glycine-Serine-Threonine; TCA_cyle; S_met - Sulphur metabolism; Arg_Pro Arginine-Proline; Glyc_lipid - glycerolipid; Sta_Suc - starch and sucrose; PS - photosynthesis; PS_Pig - photosynthetic pigments; Glycan_biosyn - glycan biosynthesis; Cyst_Met - cysteinemethionine; Phe_Tyr_Trp - Phenylalanine-Tyrosine-Trytophan.

A 165 Bacterial Family Composition

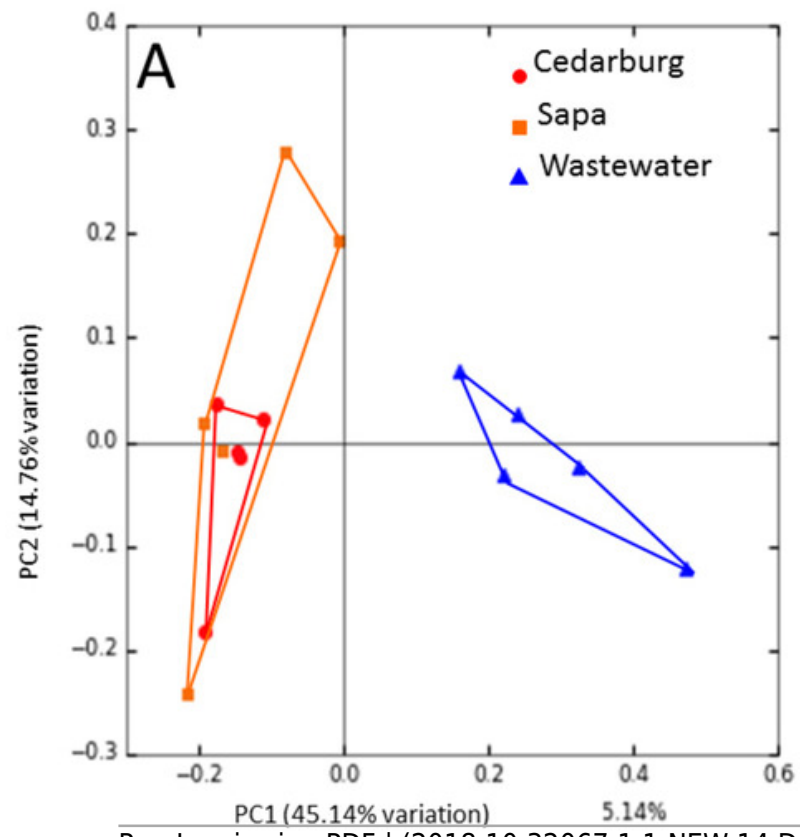

B 165 Bacterial Metabolic Functions

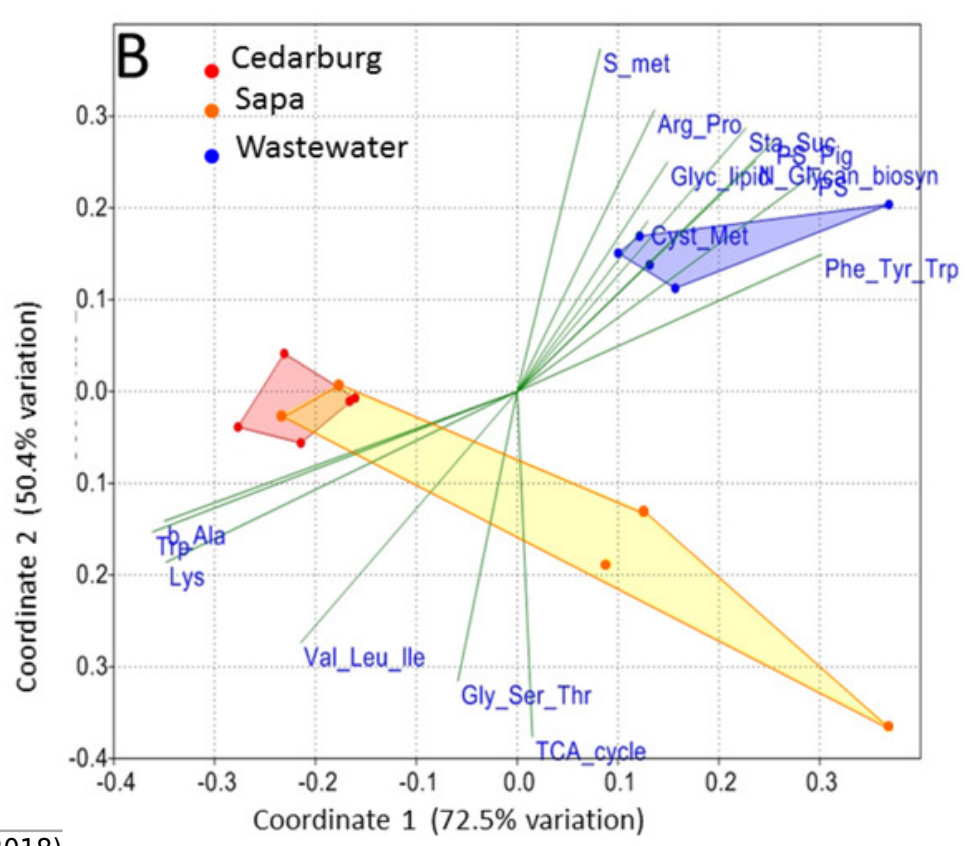




\section{Figure 5}

PCoA of pitcher plant eukaryotic taxa in two populations

A. PCoA score plot based on composition of eukaryotic taxa (18S rRNA sequences) identified in 5 pitcher samples from each wetland, compared with a curated freshwater Eukbase database from SILVA NR108. Convex hulls overlay the sample points for each group, showing overlap between the two wetland populations which are distinct from the Eukbase outgroup. B. NMDS plot of community composition, using the most common 16 eukaryotic families as vectors to separate Cedarburg and Sapa samples, with correlation as the similarity measure.
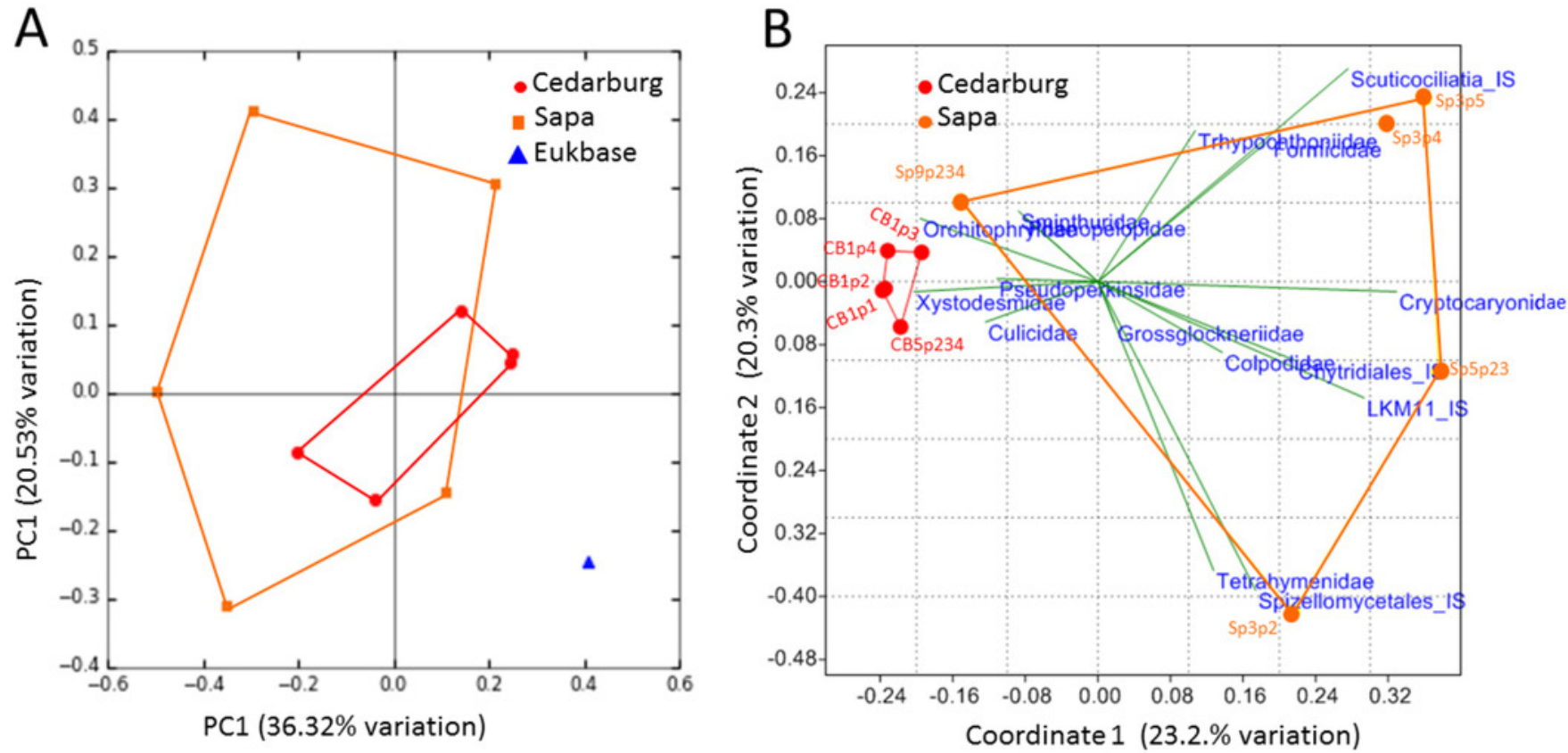


\section{Figure 6}

Relatedness trees for samples in two populations based on $16 \mathrm{~S}$ and $18 \mathrm{~S}$ rRNA sequences

Genetic diversity trees of samples from Cedarburg Bog and Sapa Bog based on $16 \mathrm{~S}$ bacterial (A) and $18 \mathrm{~S}$ eukaryotic (B) composition of taxa identified in 5 pitcher fluid samples from each population. Bootstrap values for jackknife trees generated in QIIME were based on 100 iterations with a minimum of $75 \%$ of the smallest sample sequence number. Cedarburg (CB) sample branches are black while Sapa (Sp) sample branches are grey. Bacterial composition of samples is compared with pooled wastewater outgroup (WW), and a curated freshwater EUKBASE database from SILVA.
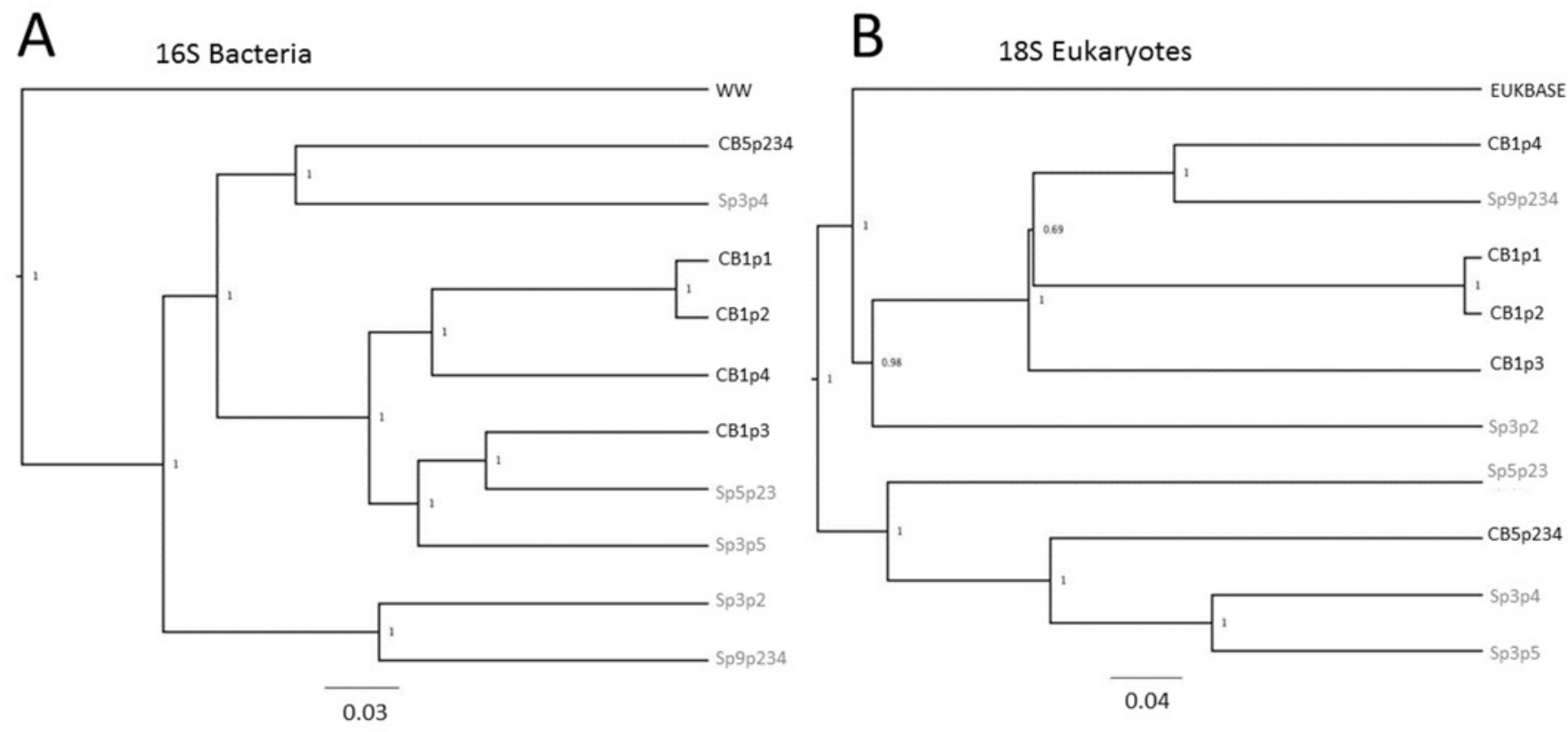